\title{
A Fiber Optic Wind Vane: A Conceptual View (U)
}

by

M. J. Parker

Westinghouse Savannah River Company

Savannah River Site

Aiken, South Carolina 29808

M. Heaverly

Met One Instruments, inc.

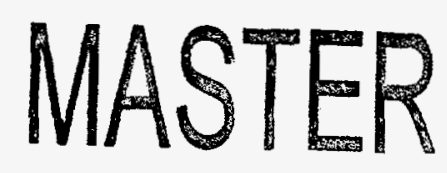

A document prepared for FOURTH NUCLEAR UTILITY METEOROLOGICAL DATA USERS GROUP MEETING at San Francisco from 04/25/96 - 04/26/96.

DOE Contract No. DE-AC09-89SR18035

This paper was prepared in connection with work done under the above contract number with the U.S.

Department of Energy. By acceptance of this paper, the publisher and/or recipient acknowledges the U.S. Government's right to retain a nonexclusive, royalty-free license in and to any copyright covering this paper, along with the right to reproduce and to authorize others to reproduce all or part of the copyrighted paper. 


\section{DISCLAIMER}

Portions of this document may be illegible in electronic image products. Images are produced from the best available original document. 


\section{DISCLAIMER}

This report was prepared as an account of work sponsored by an agency of the United States Government. Neither the United States Govemment nor any agency thereof, nor any of their employees, makes any warranty, express or implied. or assumes any legal liability or responsibility for the accuracy. completeness, or usefulness of any information, apparatus, product, of process disclosed, or represents that its use would not infringe privately owned rights. Reference herein to any specific commercial product, process, or service by trade name, trademark. manufacturer, or otherwise does not necessarily constitute or imply its endorsement, recommendation, or favoring by the United States Government or any agency thereof. The views and opinions of authors expressed herein do not necessarily state or reflect those of the United States Government or any agency thereof.

This repor has been reproduced directly from the best available copy.

Available to DOE and DOE contractors from the Office of Scientific and Technical Information. P. O. Box 62, Oak Ridge. TN 37831; prices available from (615) $576-8401$.

Available to the public from the National Technical Information Service, U. S. Department of Commerce, 5285 Port Royal Rd., Springfield. VA 22161 


\title{
A Fiber Optic Wind Vane: A Conceptual View
}

\author{
Matthew J. Parker \\ Savannah River Technology Center \\ Westinghouse Savannah River Company \\ Aiken, South Carolina \\ Matthew Heverly \\ Met One Instruments, Incorporated \\ Grants Pass, Oregon
}

\section{Introduction}

The use of tall towers for the normal operation of meteorological instrumentation is ideal for ensuring that representative measurements are obtained relative to the nearby terrain. Tall towers also expose instrumentation to unwanted environmental "side-effects" such as lightning surges. The proximity of many industrial observation sites for meteorological towers also introduces unwanted problems including radio frequency interference (RFI) from radio, television, or microwave transmitters, explosive environments, and electrical power cabling. Typical meteorological instrumentation systems incorporate protective mechanisms such as grounding networks, surge protectors and electrical shielding to combat electrical problems. Still, even with elaborate protective systems, damages to instrumentation and a loss of valid data can occur which often results in extended outages.

The use of fiber optic technology in meteorological instrumentation holds great promise to eliminate many of the problems associated with monitoring on tall towers. A fiber optic sensor would be impervious to lightning surges and all forms of RFI. The sensor would provide a high signal to noise ratio output since little or no electrical interference would be involved in data transmission. A longer field life for mechanical devices such as a wind vane would be realized since all physical contact points, such as those found in a potentiometer, would be eliminated. Therefore, the precision, resolution, linearity, starting threshold and accurăcy could be dramatically improved without the hindrance of moving parts.

\section{Rationale and Need: Two Viewpoints}

Both Met One Instruments, Inc. and Westinghouse Savannah River Company have similar views pertaining to the need for the development of a fiber optic based wind vane. The manner in which the two companies developed these 
views are somewhat different, however. In the end, the two companies have teamed together to attain the common goal of creating a fiber optic wind vane.

\section{Met One}

The potential gains from a fiber optic wind direction sensor are headed by the opportunity for unsurpassed accuracy. With a 9-bit optical encoder, direction can be measured to $\pm 0.7^{\circ}$ compared to $\pm 3^{\circ}$ for a potentiometer. This amounts to an increase of 4 times the typical wind direction sensor accuracy.

The ability to isolate sensitive opto-electronic components to an enclosure totally protected from harsh environments will considerably increase the ruggedness of the sensor. Fiber optic signals can be transmitted over long distances without concern for ground potential. Susceptibility to vibration and shock of the sensor as well as high ambient temperatures can be reduced during an appropriate robust manufacturing process.

Initially, the cost of a fiber optic wind direction sensor will be relatively high due to increased manufacturing costs. Therefore, the targeted customers will be companies or institutions seeking a very accurate sensor or having an application for monitoring in a harsh environment.

\section{Westinghouse Savannah River Company (WSRC)}

In the mid-1960's, meteorological instrumentation was installed (Parker and Addis, 1993) on a 1,200 ft television tower located near the Savannah River Site (previously known as the Savannah River Plant) to conduct a study of proposed tall reactor stacks. This meteorological monitoring system has remained in-use since then although several upgrades have occurred. A network of nine meteorological observation towers have also been installed within the confines of the Savannah River Site. In all cases, damages from lightning occur despite robust grounding systems. RFI at the television tower has long been a hindrance particularly to measurements taken near a local radio station transmitter. The use of fiber optic technology would be very beneficial in eliminating these problems.

\section{Cooperative Research and Development Agreement}

A Cooperative Research and Development Agreement (CRADA) between Met One Instruments and WSRC was created to build and test a fiber optic measurement based wind vane. This CRADA was enacted after discussions during a previous CRADA between Met One and WSRC to develop an aerodynamically improved wind vane revealed that a mutual interest in a fiber optic sensor was in place. The agreement was originally scheduled to cover about ten months, but an extension for an additional 9 months was implemented. 
The essential plan called for Met One to build the prototype sensor and for WSRC to test the prototype in a wind tunnel and in the field. Collaboration during the entire development process has occurred.

\section{Conceptual Plan: Development in Progress}

The completion of this CRADA is not planned until September, 1996. However, at this time a conceptual plan for the project can be provided. Details for some of the components of the plan are purposely missing since the final product and report must be reviewed and approved by both Met One and WSRC before the dissemination of information is allowed as stated by the CRADA contract.

Figure 1 shows a schematic of the fiber optic wind vane measurement process. A light source is located in a nearby data building structure. Light travels through fiber optic cabling to the wind vane sensor. The vane's orientation is encoded into a light signal which travels from the wind vane via fiber optic cabling back to the data building. The light signal is converted into a digital signal (analog to digital), and the digital signal is conditioned through a logic module. The final output indicates the orientation of the wind vane.

To date, an instrument prototype has been conceived. This prototype is expected to be combined with the fiber optic cabling to produce a working fiber optic sensor. Also, a method of reducing the number of fiber optic cables from a multiple number to single fiber (Figure 2) has been submitted as an invention disclosure. Reducing the number of fibers would simplify installation and lower costs for the fiber optic wind vane. "Ruggedization" of the sensor and fibers will be a primary concern for developing a commercially viable sensor. Proper connectors for the sensor will also have to be adapted.

\section{Path Forward}

After a prototype is built by Met One, operational testing can be conducted. A wind tunnel dedicated to meteorological instrument testing and calibration is operated by WSRC. Measurements of the damping ratio, starting threshold, and distance constant will be made. Also, tests of the absolute and relative accuracy can be made. Field tests in an electromagnetically active environment will be made at the WSRC television tower meteorological monitoring facility.

A final report will be written at the end of the CRADA. If appropriate, results of the CRADA will be presented and published within meteorological venues. Approval of the final report will be made by Met One, WSRC, and the US Department of Energy. 


\section{Acknowledgments}

All work conducted by Met One Instruments, Inc. is fully funded by Met One Instruments, Inc. The work performed by WSRC has been conducted for the U. S. Department of Energy under Contract Number DE-AC09-89SR18035.

\section{References}

Parker, M. J. and R. P. Addis : 1993. Meteorological Monitoring Program (U). WSRC-TR-93-0106. Savannah River Technology Center, Westinghouse Savannah River Company, Aiken, SC 29808. 


\section{Conceptual View of the Fiber Optic Wind Vane}

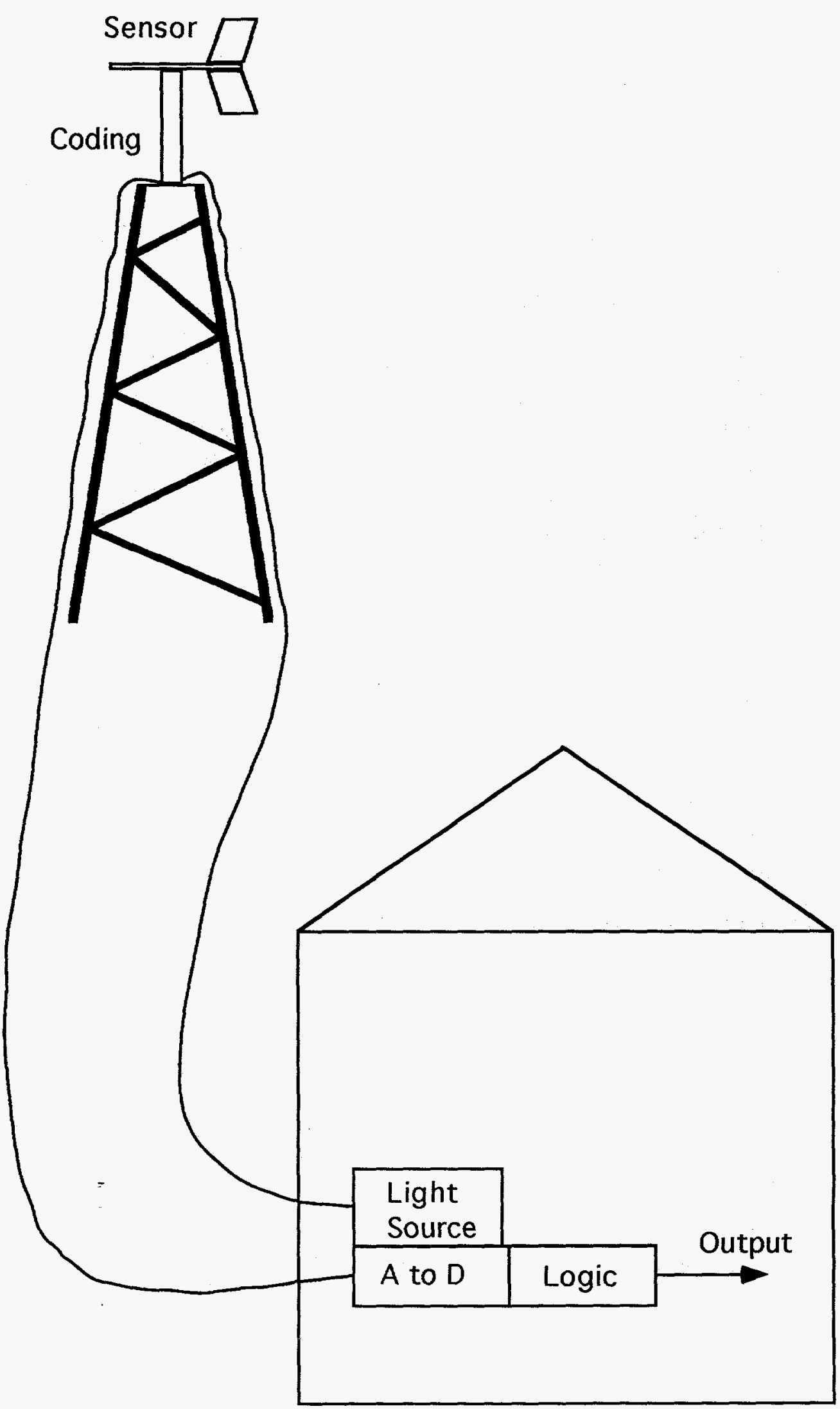

Figure 1. Schematic of the concept of the fiber optic wind vane. 
Reducing the Number of Fiber Optic Cables

Coding Device within Sensor

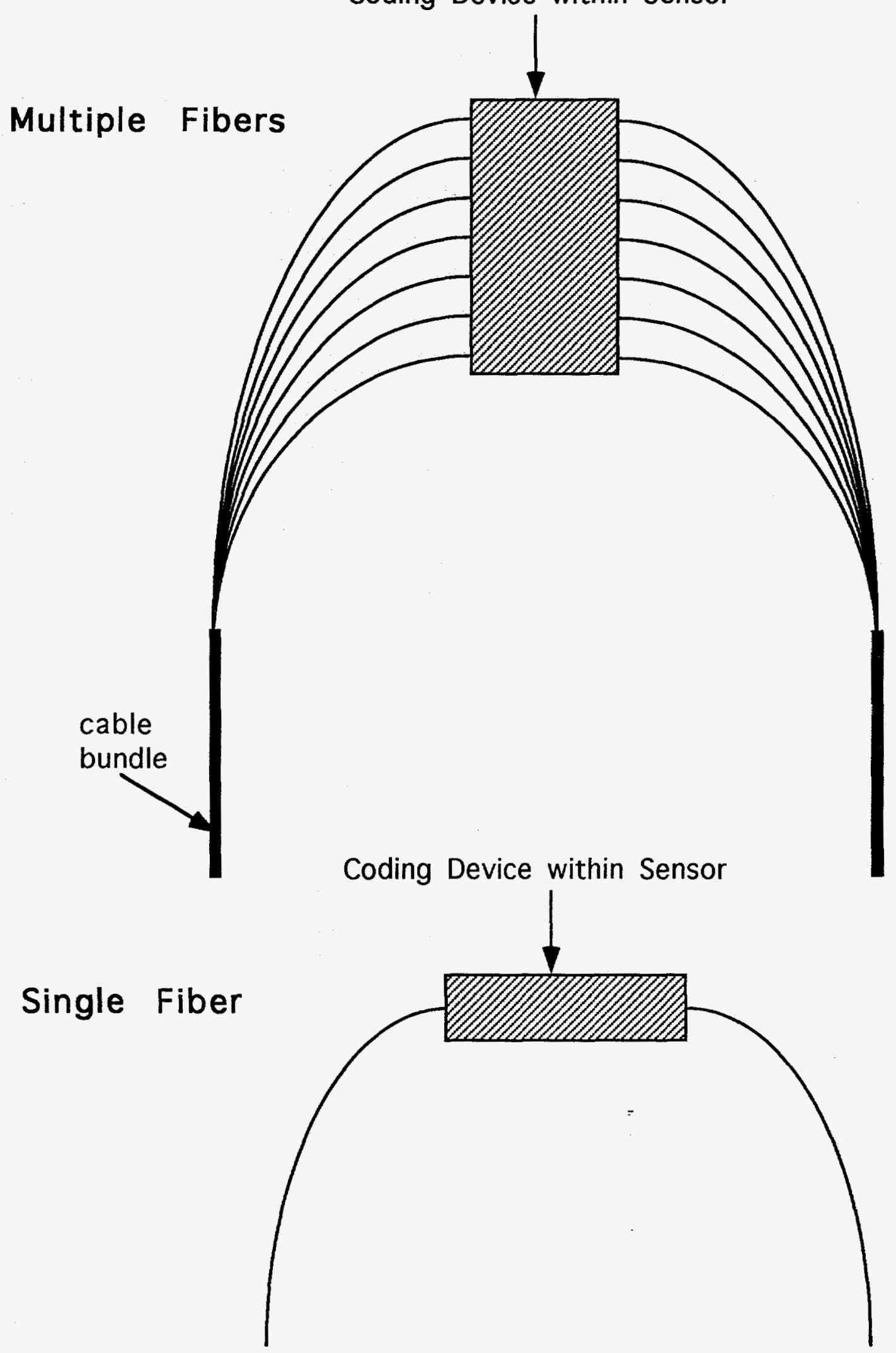

Figure 2. Method of reducing fiber optic cables from multiple to single. 